\title{
PENGEMBANGAN ASESMEN MODEL STEM PADA KONSEP TERAPUNG MELAYANG TENGGELAM UNTUK MEMFASILITASI KETERAMPILAN SAINTIFIK ANAKUSIA DINI
}

\author{
Sina Sofariah ${ }^{1}$, Edi Hendri Mulyana², Dindin Muiz Lidinilah³ \\ ${ }^{1}$ Program Studi PGPAUD Universitas Pendidikan Indonesia Kampus Tasikmalaya \\ ${ }^{2}$ Program Studi PGPAUD Universitas Pendidikan Indonesia Kampus Tasikmalaya \\ ${ }^{3}$ Program Studi PGSD Universitas Pendidikan Indonesia Kampus Tasikmalaya
}

Email : sinasofariah30@gmail.com

(Received: Mei 2020; Accepted: Mei 2020; Published: Juni 2020)

\begin{abstract}
Early Childhood Education has the principle of learning to play while learning. PAUD has a specificity in the assessment process. The assessment process is an integral part of the learning process. The assessment is holistic and includes all aspects of early childhood development. For the purpose of assessment to be achieved, educators should have knowledge of various assessment techniques. Assessment techniques in PAUD include observation, performance, work, and anecdotes. Assessment of early childhood covers all aspects of development tailored to the objectives, learning process, and learning experience of children. Assessment can be used as a tool to detect early when there are children who have problems in progress, so that will get a handlers early. Based on the underlying problem of the research, researchers chose the Educational Design Research (EDR) method that is considered to be related to the needs. The EDR method used refers to the MCKenney model \& Reeves, consisting of three stages of research i.e. analysis and exploration phase, design and construction phase and evaluation and reflection stages. As mentioned earlier, the required assessment should be in accordance with the needs of the field. So these needs are the basic idea of development. The products developed are further validated by the expert validator and are deemed worthy to be used in learning activities, especially in educational institutions that become research venues.
\end{abstract}

Keywords : Assessment, STEM, Saintific Skills

\begin{abstract}
Abstrak
Pendidikan anak usia dini memiliki prinsip dalam pembelajaran yaitu bermain sambil belajar. PAUD memiliki kekhususan dalam proses asesmen. Proses asesmen merupakan bagian yang tak terpisahkan dari proses pembelajaran. Asesmen bersifat menyeluruh (holistik) yang mencakup semua aspek perkembangan anak usia dini. Agar tujuan asesmen dapat tercapai, hendaknya pendidik memiliki pengetahuan tentang berbagai teknik penilaian. Teknik asesmen di PAUD antara lain observasi, unjuk kerja, hasil kerja, dan anekdot. Asesmen pada anak usia dini mencakup semua aspek perkembangan yang disesuaikan dengan tujuan, proses pembelajaran, serta pengalaman belajar anak. Asesmen dapat dijadikan sebagai alat untuk mendeteksi sejak dini ketika ada anak yang mengalami permasalahan dalam perkembangan, sehingga akan memperoleh penangan sejak dini. Berdasaarkan pokok permasalahan yang menjadi dasar penelitian, peneliti memilih metode Educational Design Research (EDR) yang dianggap relavan dengan kebutuhan. Metode EDR yang digunakan mengacu pada model MCKenney \& Reeves, terdiri dari tiga tahapan penelitian yakni tahap analisis dan eksplorasi, tahap desain dan kontruksi serta tahap evaluasi dan refleksi. Sebagaimana telah dijelaskan sebelumnya bahwa asesmen yang dibutuhkan harus sesuai dengan kebutuhan dilapangan. Maka berbagai kebutuhan tersebut dijadikan ide dasar pengembangan. Produk yang dikembangkan selanjutnya divalidasi oleh validator ahli dan dinyatakan layak untuk digunakan dalam kegiatan pembelajaran, khususnya di lembaga pendidikan yang menjadi tempat penelitian.
\end{abstract}

Keywords : Asesmen, STEM, keterampilan Saintifik 


\section{PENDAHULUAN}

Pendidikan awal anak usia dini sangat penting bagi tumbuh kembang seorang anak. Menurut Undang-undang Nomor 20 Tahun 2003 Bab Pasal 1 ayat (14) ditegaskan bahwa Pendidikan Anak Usia Dini merupakan "Suatu upaya pembinaan yang ditujukan kepada anak sejak lahir sampai dengan usia enam tahun yang dilakukan melalui pemberian rangsangan pendidikan yang membantu pertumbuhan dan perkembangan jasmani dan rohani agar anak memiliki kesiapan dalam memasuki pendidikan lebih lanjut. Sejalan dengan penjelasan tersebut, sujiono (2012, hlm. 6) Menurut Undang-undang Nomor 20 Tahun 2003 Bab Pasal 1 ayat (14) ditegaskan bahwa Pendidikan Anak Usia Dini merupakan "Suatu upaya pembinaan yang ditujukan kepada anak sejak lahir sampai dengan usia enam tahun yang dilakukan melalui pemberian rangsangan pendidikan yang membantu pertumbuhan dan perkembangan jasmani dan rohani agar anak memiliki kesiapan dalam memasuki pendidikan lebih lanjut. Penerapan kurikulum 2013 sangat erat kaitannya dengan karakteristik abad 21 dimana tuntutan terhadap kompetensi berpikir semakin berkembang. Kurikulum 2013 juga diarahkan untuk mengembangkan keterampilan abad 21, yang dimaksud dengan abad 21 yaitu meliputi kompetensi-kompetensi seperti kompetensi berpikir kritis, kemampuan berpikir kreatif, kemampuan berkolaborasi dan berkomunikasi, serta kemampuan menguasai media teknologi informasi dan komunikasi. Anak harus memiliki keterampilan abad 21 agar anak dapat bersaing, bukan hanya dengan rekan sebangsanya, tetapi juga rekan seusianya di negara lain karena persaingan yang semakin ketat di era globalisasi ini mengharuskan sumber daya manusia memiliki kualitas yang baik dan professional di berbagai bidang kehidupan. Pembelajaran konsep sains di PAUD diperkenalkan pada anak untuk membantu anak dalam pemahaman konsep sebab akibat serta melatih anak untuk mengeksplor dan menganalisis masalah yang dihadapinya dengan menggunakan panca inderanya. Konsep pembelajaran sains di PAUD masih sangat rendah,karena banyak pendapat bahwa pembelajaran sains pada anak masih dianggap terlalu sulit untuk dipelajari. Namun sebenarnya banyak pembelajaran konsep sains yang bisa diajarkan pada anak usia dini. Pembelajaran sains pada anak dapat dilakukan dengan kegiatan permainan sains sederhana seperti permainan sains "terapung, melayang dan tenggelam" dengan Hukum Archimides.

Pembelajaran berbasis pendekatan saintifik proses pembelajaran yang dirancang agar peserta didik secara aktif. Oleh karena itu, meskipun kurikulum pendidikan anak usia dini (kurikulum 2013) 
tidak memiliki bagian khusus yang membahas tentang kurikulum pembelajaran sains, pendekatan saintifik ditetapkan untuk menjadi ciri khas kurikulum PAUD. Kurikulum 2013 pada hakikatnya menitikberatkan pada pengembangan sains sebagai proses atau yang disebut dengan keterampilan proses sains. pendekatan saintifik didefinisikan sebagai sebuah pendekatan atau membangun pola pikir dan daya nalar anak melalui lima tahapan yaitu: Mengamati, menanya, mengumpulkan informasi, Menalar dan mengkomunikasikan. Pentingnya pembelajaran model STEM untuk PAUD karena menekankan pada pembelajaran aktif, menstimulasi anak untuk memecahkan masalah, fokus pada solusi dan membangun cara berpikir secara logis dengan sistematis serta mempertajam kemampuan berpikir kritis. Namun berdasarkan observasi kebeberapa TK masih jarang sekolah yang diterapkannya pembelajaran berbasis STEM serta pendidik belum mengetahui tentang pembelajaran berbasis STEM. Sehingga belum terdapat penilaian secara khusus mengenai pembelajaran berbasis STEM di TK tersebut.

Asesmen adalah proses pengumpulan informasi atau data yang digunakan untuk membuat keputusan tentang pembelajaran. Pembelajaran yang dimaksud mencakup siswa, kurikulum, program, dan kebijakan. Proses penilaian juga meliputi pengumpulan bukti-bukti tentang pencapaian belajar siswa. Bukti ini tidak selalu diperolah melalui tes saja, tetapi juga bisa dikumpulkan melalui non tes atau melalui pengamatan dan laporan diri. Pelaksanaan penilaian harus dilaksanakan secara intensif dan teratur supaya menumbuhkan kebiasaan yang baik bagi siswa. Penilaiaan pada anak usia dini menurut Iswantiningtyas dan Wulansari (2018) dilakukan dengan mengadakan suatu pengamatan, pencatatan dan dokumentasi tentang kegiataan anak. Penilaiaan tidak hanya digunakan untuk mengukur keberhasilan suatu program, akan tetapi untuk memantau kemajuan dan perkembangan belajar anak.

Asesmen yang dilakukan pada anak yang duduk di PAUD tentunya berbeda dengan asesmen yang diperuntukkan bagi individu yang dewasa. Hal ini didasarkan pada beberapa alasan, yaitu ketidakmampuan anak usia dini dalam hal baca tulis serta karakteristik perkembangan anak yang unik sehingga membutuhkan strategi pengukuran yang berbeda pula. Asesmen pada PAUD tidak mengenal ulangan, ujian, apalagi tes objektif.Untuk mengukur perkembangan di PAUD hal yang dilakukan adalah dengan mengobservasi, mencatat dan mendokumentasikan segala sesuatu tentang anak, baik perkembangannya, perilaku, maupun hasil karyanya. 
Penelitian ini menggunakan metode Educational Design Research, namun penelitian ini dilakukan secara terbatas, hanya sampai tahap II, yaitu rancangan dan pembuatan terhadap produk yang dikembangkan dan validasi ahli. Perancangan produk ini tidak di ujicobakan karena tidak memungkinkan pelaksanaan uji coba penelitian kelapangan sedang terjadi wabah pandemic Covid-19 di seluruh dunia termasuk Indonesia,khususnya di Kota Tasikmalaya.

Adanya permasalahan ini Peneliti berminat untuk mengembangkan asesmen pembelajaran yang dapat digunakan sebagai penunjang penilaian konsep terapung, melayang dan tenggelam anak usia dini untuk menfasilitasi keterampilan saintifik anak usia dini. Maka dari itu penelti tertarik untuk melakukan penelitian dengan judul “ Pengembangan Asesmen Pembelajaran Model STEM pada Konsep Terapung, Melayang dan Tenggelam untuk Memfasilitasi Keterampilan Saintifik Anak Usia Dini”.

\section{TINJAUAN PUSTAKA}

\section{a. Pendidikan Anak Usia Dini}

Anak adalah manusia kecil yang memiliki potensi yang harus di kembangkan. anak memiliki karakteristik tertentu yang khas dan tidak sama dengan orang dewasa, mereka selalu aktif dan ingin tahu terhadap apa yang dilihat, didengar, dirasakan mereka seolah-olah tidak pernah berhenti bereksplorasi dan belajar. Anak bersifat egosentris, memiliki rasa ingin tahu secara alamiah, unik, kaya dengan fantasi, serta memiliki daya konsentrasi yang sedikit, dan merupakan masa yang paling potensial untuk belajar. Anak usia dini adalah sosok individu yang sedang menjalani suatu proses perkembangan dengan pesat dan fundamental. Anak usia dini (Sujiono, 2009:6) adalah sosok individu yang sedang menjalani suatu proses perkembangan dengan pesat dan fundamental bagi kehidupan selanjutnya. Menurut Isjoni (2011, hlm.19) menyatakan bahwa anak usia usia empat-enam tahun merupakan bagian dari anak usia dini yang secara terminologi disebut sebagai anak usia prasekolah.

b. Pembelajaran Sains (Konsep Terapung Melayang Tenggelam) untuk Anak Usia Dini

Pembelajaran sains merupakan suatu upaya yangdigunakan untuk menstimulasi aspek perkembangan dan memaksimalkan potensi yang ada dalam diri anak . Dengan kata lain, dalam proses pembelajaran sains, bukan konsep sains yang ditekankan untuk dipahami oleh anak, namun lebih mengarah kepada bagaimana pembelajaran sains tersebut mampu menjadi alat untuk menstimulasi berbagai aspek perkembangan anak sejak dini. Tujuan pembelajaran sains bagi anak adalah mengembangkan aspek perkembangandan 
potensi yang dimiliki anak. Selain itu pembelajaran sains juga ditujukan untukmengembangkan individu agar mengenal ruang lingkup sains itu sendiri serta mampumenggunakan aspek-aspek fundamental dalam memecahkan masalah yang dihadapinya. Perkembangan sains anak usia dini dalam penelitian adalah agar anak dapat mengetahui bagaimana benda bisa tenggelam terapung dan melayang. Hukum Archimedes merupakan suatu materi yang dapat kita amati dalam kehidupan sehari-hari. Anak usia dini pun harus mengetahui dan memperlajari setiap peristiwa yang mereka lihat. Kita ketahui bahwa banyak fenomena didunia ini yang mengandung ilmu pengetahuan, termasuk konsep sains terapung melayang tenggelam. Pada konsep sains ini kita bisa ajarkan pada jenjang usia dini karena behubungan dengan fenomena yang ada disekililing kita. Pembelajaran mengenai konsep terapung, melayang dan tenggelam ini dapat kita sampaikan kepada anak melalui pendekatan saintifik. Menurut Utami, dkk (2014, hlm. 62) dasar hokum archimedes "Hukum Archimendes adalah sebuah hukum tentang prinsip pengapungan di atas zat cair, pada prinsip archimendes sebuah benda akan mengapung dalam fluida jika massa jenis suatu benda lebih kecil dari pada massa jenis zat cair." Dengan adanya gaya Archimedes dalam zat cair, benda yang dicelupkan ke dalamnya akan mengalami tiga kemungkinan. Tiga kemungkinan tersebut yaitu terapung, melayang dan tenggelam. Jika dalam sebuah tempat air dalam keadaan tenang, maka di seluruh bagian air tekanannya sama. Kalua ada daerah yang tekanannya berbeda, maka air dari tempat yang tekanannya tinggi mengalir kea rah yang tekanannya rendah. Jika benda dimasukkan ke dalam air dan setelah airnya tenang kembali benda terapung, keadaan itu menunjukan bahwa tekanannya menjadi sama dimana-mana. Perkembangan sains anak usia dini dalam penelitian adalah agar anak dapat mengetahui bagaimana benda bisa terapung melayang tenggelam melalui media permainan sains Sink Float and Fun yang dibuat oleh kolaborasi dari tim penelitian. Anak bisa membedakan konsep tenggelam terapung dan melayang, mengapa benda bisa terapung melayang dan tenggelam. Lalu bisa diterapkan dalam kehidupan sehari-hari.pembelajaran dengan media permainan sains tersebut bias lebih menyenangkan untuk anak dan bisa memperkatekannya sendiri, sehingga menarik untuk anak.

Jadi dapat disimpulkan diatas bahwa terdapat dalam pembelajaran sains terapung melayang tenggelam melalui media permainan sains Sink Float and Fun yang sudah dibuat secara kolaborasi dalam tim penelitian, dengan demikian anak bisa paham dan dapat membedakan bendabenda yang bisa terapung melayang dan tenggelam. 
c. Keterampilan Saintifik Anak Usia Dini

Sehubungan dengan pendidikan di Indonesia yang sudah menerapkan kurikulum 2013 dimana lebih menekankan untuk menggunakan pendekatan saintifik, maka anak dianjurkan untuk menguasai keterampilan saintifik. Dalam Permendikbud No. 146 Tahun 2014 menyatakan bahwa kurikulum dirancang dengan karakteristik menggunakan pembelajaran tematik dengan pendekatan saintifik dalam pemberian rangsangan pendidikan. Sehubungan dengan hal tersebut, pendekatan yang tertera dalam kurikulum 2013 Pendidikan Anak Usia Dini (PAUD) yaitu Tematik Integratif, pendekatan Santifik, Bermain Kreatif, dan Kecerdasan jamak. Pendekatan Tematik integratif dan saintifk sangat berkaitan dalam pembelajaran untuk anak usia dini. Pendekatan tersebut merupakan pendekatan yang paling utama dalam pembelajaran PAUD, terutama dalam mengembangkan keterampilan saintifik. Keterampilan saintifik tersebut menurut Peraturan Menteri Pendidikan dan Kebudayaan Republik Indonesia Nomor 146 Tahun 2014, yaitu: mengamati; menanya; mengumpulkan informasi; menalar dan mengomunikasikan hasil. Dari pernyataan tersebut dapat disimpulkan bahwa pembelajaran yang dilakukan untuk anak usia dini sebaiknya menggunakan pendektan saintifik.

\section{d. Pembelajaran STEM}

Salah satu pembelajaran yang relevan dengan pengembangan keterampilan abad ke-21 adalah pendidikan STEM (Sulistia, S. dkk, 2019, hlm. 1). STEM adalah pendekatan pembelajaran terpadu yang menghubungkan pengaplikasian di dunia nyata dengan pembelajaran di dalam kelas maupun di luar kelas yang meliputi empat disiplin ilmu yaitu Science, Technology, Engineering, and Mathematics. "STEM", dimulai dengan "SMET", diperkenalkan oleh National Science Foundation (NSF) untuk menekankan pentingnya empat disiplin ilmu baik sebagai kompetensi pekerja dan kompetensi siswa (Lidinillah, dkk, 2019, hlm. 1). Pendidikan STEM merujuk pada empat ilmu pengetahuan yaitu sains, teknologi, teknik, dan matematika.

\section{1) Science/Sains}

Sains adalah kumpulan pengetahuan tentang dunia fisik dan alam. Ilmuwan berusaha menggambarkan, menjelaskan, dan memprediksi dunia alami dan sifat fisiknya. Domain ilmu pengetahuan mencakup ilmu kehidupan, ilmu bumi dan ruang, ilmu fisika dan bidangbidang lain yang umumnya digunakan untuk membangun pemahaman tentang dunia dan menyelidiki bagaimana dunia bekerja. Pada saat ini banyak pembelajaran yang memperkenalkan anak pada 
pengalaman dan interaksi

pembelajaran konseptual dan

kemampuan dalam penyelidikan sains.

2) Tecnologhy/ Teknologi

Teknologi mencakup semua alat digital dan nondigital buatan manusia yang kita gunakan untuk memahami sciense, menyelesaikan masalah kita, memenuhi kebutuhan dan keinginan kita dan menavigasi dunia kita, secara virtual dan nyata.

Teknologi diproduksi oleh manusia untuk menyelesaikan masalah atau memenuhi kebutuhan dan merupakan produk dari proses rekayasa.

3) Engeneering/ Teknik

Bidang teknik adalah tempat disiplin ilmu, teknologi, dan matematika bersatu, di sinilah masalah dipecahkan melalui penciptaan solusi; objek, sistem atau proses yang dirancang untuk memenuhi kebutuhan manusia atau membuat hidup lebih baik. Teknik adalah aplikasi pengetahuan untuk merancang, membangun, dan memelihara teknologi secara kreatif.

\section{4) Matchematic/ Matematika}

Matematika adalah cara mengukur. Sulistia, S. et al. (2019, hlm. 2) "Matematika adalah" ilmu angka, jumlah, dan bentuk dan hubungan di antara mereka. Matematika menggunakan angka dan simbol untuk menggambarkan hubungan antar konsehlm. Mani disiplin ilmu lain, termasuk sains dan teknik, sering menggunakan "bahasa matematika.

e. Asesmen

Asesmen atau disebut juga dengan penilaian adalah suatu penerapan dan penggunaan berbagai cara dan alat untuk mendapatkan serangkaian informasi tentang hasil belajar dan pencapian kompetensi dari peserta didik. Asesmen keterampilan saintifik merupakan sebuah penilaian yang mengharuskan peserta didik melaksanakan suatu tugas untuk menilai ketercapaian kompetensi peserta didik. Berdasarkan hal tersebut, dapat disimpulkan bahwa asesmen keterampilan saintifik termasuk ke dalam asesmen kinerja/unjuk kerja. Teknik yang dipilih peneliti yakni rubrik (rubric). Rubrik adalah seperangkat pedoman penilaian untuk mengevaluasi pekerjaan anak. Rubrik menjawab pertanyaan tentang kriteria apa yang harus kita cari untuk menilai keberhasilan kinerja, seperti apakah kisaran kualitas penampilan, bagaimana kita menentukan secara valid, andal, dan adil, kemudian apa skor yang harus diberikan dan apa artinya skor itu, serta bagaimana seharusnya tingkat kualitas 
yang berbeda dapat dijelaskan dan dibedakan satu sama lain

Penilaian merupakan komponen penting dalam penyelenggaraan pendidikan. Penilaian adalah upaya sistematik dan sistemik yang dilakukan melalui pengumpulan data atau informasi yang sahih (valid) dan reliabel, dan selanjutnya data indormasi tersebut diolah sebagai upaya melakukan pertimbangan untuk pengambilan kebijakan suatu program pendidikan (Sani, 2016, hlm. 15). STEM pada pelaksanaanya yaitu memadukan konten maupun konteks antara sains, teknologi, teknik, dan matematika untuk mengembangkan kemampuan siswa dengan proses pemecahan dalam dunia nyata. Pendidikan STEM merujuk pada empat ilmu pengetahuan yaitu sains, teknologi, teknik, dan matematika. "Pembelajaran berbasis STEM dapat melatih siswa dalam menerapkan pengetahuannya untuk membuat desain sebagai bentuk pemecahan masalah terkait lingkungan dengan memanfaatkan teknologi" (Permanasari, 2016, hlm. 29). Penerapan pengetahuan siswa dapat berkembang dan siswa mampu menghasilkan sebuah karya dan dapat memecahkan permasalahan yang cukup kompleks dengan bantuan integrasi pembelajaran berbasis STEM.

Sejalan dengan itu Permendikbud No. 146 Tahun 2014 penlaian proses dan hasil kegiatan belajar PAUD, adalah suatu proses mengumpulkan dan mengkaji berbagai informasi secara sistematis, terukur, berkelanjutan, serta menyeluruh tentang pertumbuhan dan perkembangan yang telah dicapai oleh anak selama kurun waktu yang telah ditentukan dalam pembelajaran.

\section{METODE}

Metode penelitian secara umum diartikan sebagai cara ilmiah untuk mendapatkan data dengan tujuan dan kegunaanya. Penelitian yang dapat memecahkan masalah pendidikan, misalnya menemukan model pembelajaran yang efektif, metode pembelajaran yang tepat termasuk pada metode penelitian pendidkan. Metode penelitian pendidikan menurut Sugiyono (2015, hlm. 6) diartikan sebagai cara ilmiah untuk mendapatkan data yang valid dengan tujuan dapat ditemukan, dikembangkan, dan dibuktikan, suatu pengetahuan tertentu sehingga pada gilirannya dapat digunakan untuk memahami, memecahkan dan mengantisipasi masalah dalam bidang pendidikan. Penelitian menggunakan pendekatan penelitian campuran (mix method) dengan jenis pengembangan Educational Design Research (EDR). Menurut (dalam Lidinillah, 2012) Educational Design Research yaitu "serangkaian pendekatan, dengan maksud untuk menghasilkan teori-teori baru, artefak, dan model praktis yang menjelaskan dan berpotensi berdampak pada pembelajaran dengan pengaturan yang alami (naturalistic)".

Sejalan dengan pengertian tersebut Lagemann (dalam McKenney dan Reeves 
2012, hlm. 7) bahawa desain penelitian pendidikan disebut sebagai pengetahuan yang dapat digunakan, sehingga menghasilkan produk penelitian yang relevan untuk praktik pendidikan.

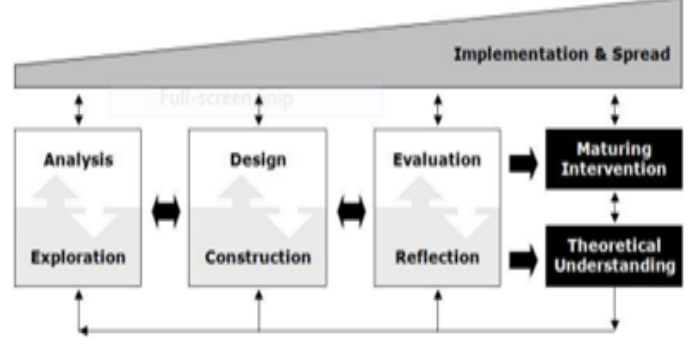

Dari gambar diatas menjelaskan bahwa proses penelitian EDR memiliki tiga tahap utama. Pada penelitian ini, peneliti bermaksud untuk mengembangkan sebuah rubrik asesmen kinerja berpikir kritis, kreativitas, komunikasi, kolaborasi pada pembelajaran STEM dengan

\section{HASIL DAN PEMBAHASAN}

Penelitian ini merupakan penelitian pada konten penelitian sains yakni tentang media permainan sains terapung melayang tenggelam untuk memfasilitasi keterampilan saintifik anak usia dini. Penelitian ini bertujuan untuk menghasilkan rubrik asesmen keterampilan saintifik pada permainan sains terapung melayang tenggelam untuk memfasilitasi keterampilan saintifik anak usia dini kelompok B pada tema Transportasi, sub tema Transportasi Air dan sub-sub tema Terapung Melayang dan Tenggelam .

Pengembangan rubrik asesmen pada permainan sains terapung melayang media Terapung Melayang Tenggelam. Rubrik yang akan dikembangkan pada artikel ini merupakan bagian dari perangkat pembelajaran berbasis STEM yang dikembangkan secara tim dengan jumlah anggota sebanyak 4 orang. Masing-masing anggota memegang peran berbeda namun perangkat yang dikembangkan saling keterkaitan seperti asesmen kinerja yang berkaitan dengan RPP, LKA dan juga media pembelajaran. Berikut ini adalah tahapan penelitian yang akan dilakukan.

1) Tahap Analisis dan Eksplorasi (Analysis and Exploration)

2) Tahap Desain dan Kontruksi (Design and Construction)

3) Tahap Evalauasi dan Refleksi (Evaluation and Reflection)

tenggelam untuk memfasilitasi keterampilan saintifik anak usia dini kelompok B pada tema transportasi dilaksakan dengan menggunakan metode EDR (Educational design Research), identfikasi dan analisis masalah yang didasarkan pada patokan teori, desain prinsip dan memberikan solusi praktis. Tahap Analisis dan Eksplorasi (Analysis and Exploration)

Pada tahap ini, peneliti melakukan analisis masalah dan mengeksplorasi masalah dengan melalui studi literatur dan studi pendahuluan. Studi pendahuluan menggunakan metode wawancara dan 
studi dokumentasi. Sumber data pada tahap studi pendahuluan kebeberapa sekolah di Kota Tasikmalaya. Pada tahap studi pendahuluan akan diperoleh informasi secara langsung mengenai asesmen kinerja yang dilakukan oleh guru pada proses pembelajaran permainan sains. Hasil dari studi pendahuluan dan studi literarur ini kemudian dianalisis dan dibandingkan dengan kondisi yang seharusnya (ideal). Disini peneliti juga mencari informasi mengenai hal apa saja yang menjadi kesulitan dan hambatan guru dalam merancang asesmen terutama dalam mearancang asesmen model STEM pada konsep Terapung Melayang Tenggelam untuk Memfasilitasi Keterampilan Saintifik Anak Usia Dini .

1. Tahap Desain dan Kontruksi (Design and

\section{Construction)}

Pada tahap kedua ini, peneliti mulai menyusun rancangan desain produk yang dihasilkan dan dikembangkan. Perancangan produk ini berdasarkan teoriteori mengenai desain yang akan dibuat dan permasalahan yang dianalisis, sehingga produk yang dihasilkan dapat memecahkan masalah tersebut Dalam langkah ini peneliti merancang rubrik asesmen model STEM pada konsep terapung melayang tenggelam untuk memfasilitasi keterampilan saintifik anak usia dini pada permainan sains terapung melayang tenggelam untuk anak usia dini. Tahap mengembangkan desain pembelajaran ini difokuskan pada beberapa kegiatan, yaitu: membuat prinsip desain, menentukan Kompetensi Inti (KI) dan Kompetensi Dasar (KD), menentukan indikator dan tujuan pembelajaran, menentukan materi ajar, merancang awal rubrik asesmen, dan menentukan langkah penggunaan rubrik. peneliti mengembangkan asesmen yang menjadi solusi dari permasalahan. Permasalahan yang diteliti adalah mengenai asesmen model STEM pada konsep terapung melayang tenggelam untuk memfasilitasi keterampilan saintifik anak usia dini dalam suatu permainan sains biasanya tidak sengaja dibuat karena asesmen yang digunakan adalah penilaian anekdot, penilaian ceklis, dan penilaian hasil karya. Alasannya yaitu karena penilaian tersebut sudah tersedia dan biasa digunakan dalam menilai perkembangan anak. Selain itu, penilaian-penilaian tersebut tidak mengharuskan guru menyusun kriteria khusus dalam menilai perkembangan anak. Guru hanya perlu mengisi penilaian anekdot jika terjadi kejadian khusus atau kejadian luar biasa selama kegiatan permainan sains. Berikut tabel rubrik kinerja asesmen:

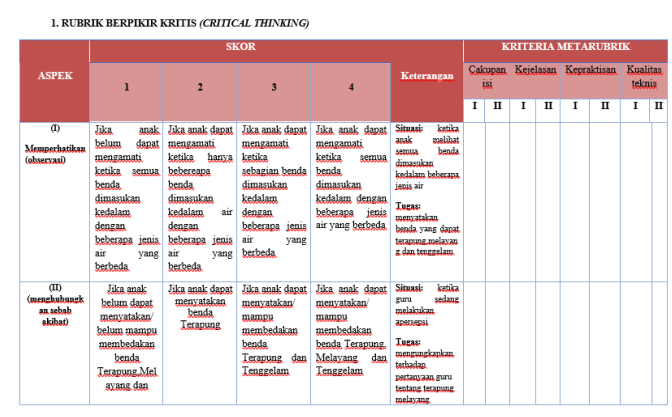


Gambar 1. Rubrik berpikir kritis

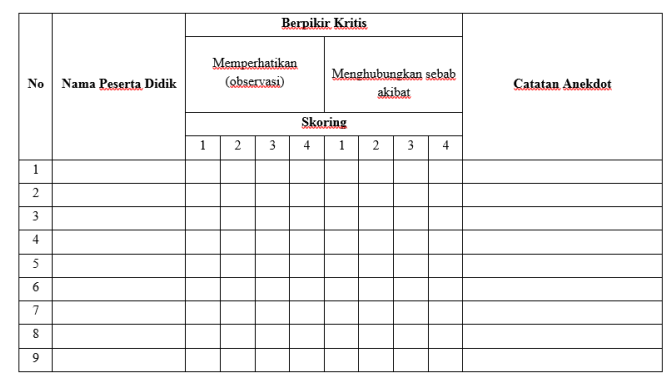

Gambar 2. Rubrik asesmen individu

Mengobservasi dan Menghubungkan sebab akibat

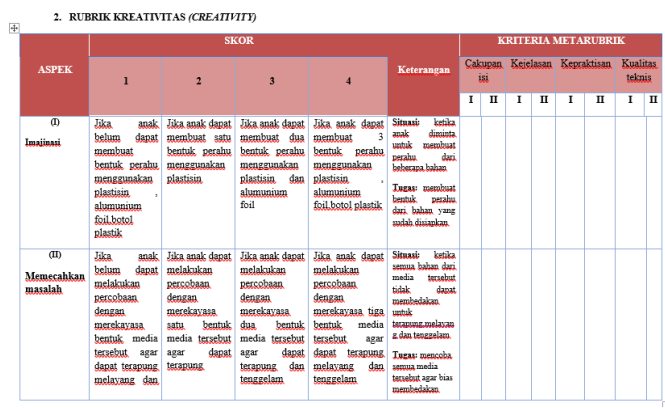

Gambar 3. Rubrik Kreativitas

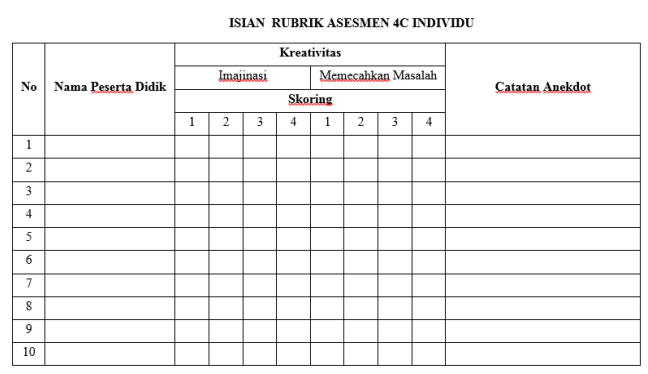

Gambar 4. Rubrik asesmen individu Imajinasi dan Memecahkan Masalah

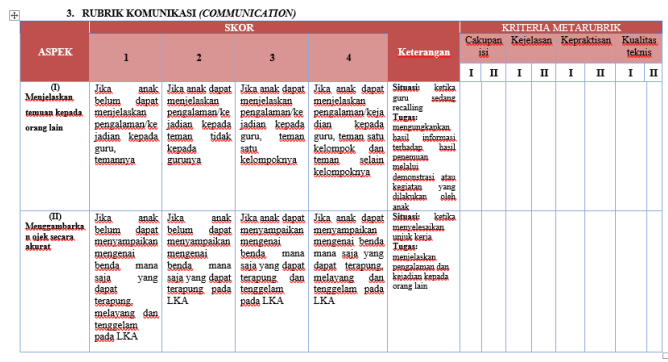

Gambar 5. Rubrik Komunikasi

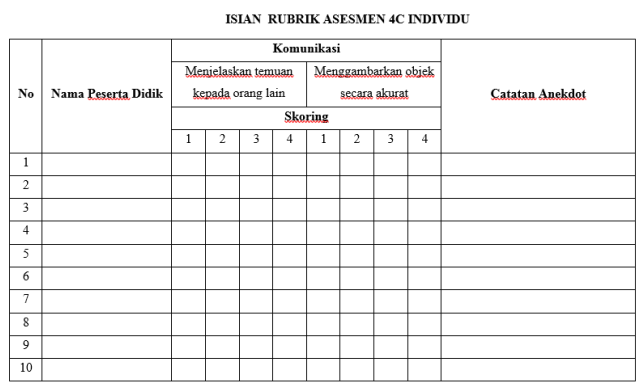

Gambar 6. Rubrik asesmen individu Menjelaskan Temuan kepada Orang Lain dan Menggambarkan Objek Secara Akurat

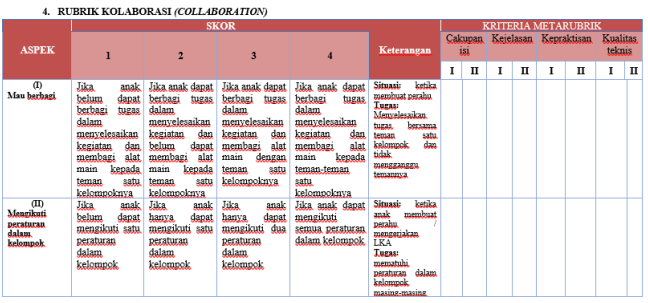

Gambar 7. Rubrik Kolaborasi

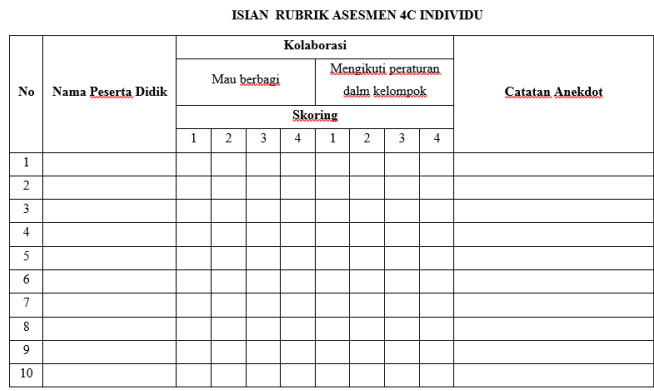

Gambar 8. Rubrik asesmen individu Mau Berbagi dan Mengikuti Peraturan dalam Kelompok

Pengembangan dalam penelitian ini melalui mengembangkan rubrik melalui penilaian $4 \mathrm{C}$ ini memudahkan guru ketika menilai anak, berbeda dengan penilaian yang dilakukan biasanya dengan rubrik catatan anekdot, catatan harian, hasil karya anak secara terpisah tetapi dalam pembuatan rubrik ini sudah meliputi semua dari bagian yang terpisah itu, hanya 
saja dalam secara penempatannya disatukan.

\section{KESIMPULAN}

Dengan dilaksanakannya proses asesmen maka dapat diperoleh karakteristik tingkat perkembangan atau performansi yang dimiliki anak. Hal ini akan bermanfaat untuk merencanakan program kaitannya memberi pelayanan untuk melihat ketercapaian anak melalui semua aspek perkmebnagan. Penilaian adalah penggunaan sistem evaluasi yang bersifat menyeluruh untuk menentukan kualitas dari suatu program atau kemajuan dari seorang anak. Penilaian di PAUD merupakan usaha mendapatkan informasi secara berkala, berkesinambungan dan menyeluruh tentang proses dan hasil dari pertumbuhan dan perkembangan yang telah dicapai oleh anak didik melalui kegiatan belajar.

Anak usia dini merupakan individu yang unik, dan mempunyai karakter yang berbeda satu dengan yang lainnya, dan suasana hati yang berubah-ubah. Jadi perkembangan atau kemajuan belajar anak usia dini merupakan proses yang sistematis tentang pengumpulan,penganalisisan dan pemberian keputusan tentang informasi yang dikumpulkan. Asesmen pada anak usia dini dengan memerhatikan prinsip-prinsipnya maka akan membantu anak mencapai tahap perkembangan sesuai dengan usianya. Dengan asesmen dan teknik penilaian yang tepat maka Permendikbud RI Nomor 146 tahun 2014 tentang Kurikulum 2013 Pendidikan Anak Usia Dini akan membantu pendidik untuk mempersiapkan proses pembelajaran sesuai dengan kebutuhan anak serta dapat dilaporkan perkembangan anak kepada orang tua. Dalam penelitian ini, informasi yang didapat adalah informasi tentang perkembangan anak yang didapat dengan mengimplementasikan teknikteknik asesmen baik yang bersifat formal maupun informal selain itu asesmen dapat dijadikan alat untuk mendeteksi sejak dini

\section{SARAN}

Saran dari penulis untuk permasalahan ini yaitu diharapkan guru lebih memperhatikan pencapaian atau perkembangan anak melalui semua aspek perkembangan . tidak hanya soal evaluasi yang biasa dilakukan seperti biasa saja, tetapi dengan menggunakan rubrik penilaian yang khusus menilai dari model STEM ini. Diharapkan juga guru rubrik ini memuat atau memfasilitasi pada penilaian untuk saintifik anak usia dini.

\section{DAFTAR PUSTAKA}

Lidinillah, D., A., M (2012). Educational Design Research: Theoretical Framework For AAction.

McKenney \& Reeves. (2012). Educational Design Reasearch. London: Routledge Sani, R.A. (2016). Penilaian Autentik. Jakarta: Bumi Aksara. 
Selly, P.B. (2017). Teaching STEM Outdoors Activities for Young Children. Amerika Serikat: Redleaf PRESS.

Permanasari, A. (2016). STEM Education: Inovasi dalam Pembelajaran Sains. Surakarta: Universitas Sebelas Maret

Sulistia, S., dkk, (2019). Promoting Engineering for Fourth-Grade Students Through STEM Learning. Journal of Physics: Conf. Series, 1318(1), 1-6.
Utami,T. (2017) Penanaman Kompetensi Inti Melalui Pendekatan Saintifik di PAUD Terpadu An-Nur: Jurnal Pendidikan Anak Usia Dini, 1 (2), 91-1-100.

Isjoni (2011). Model Pembelajaaran Anak Usia Dini. Bandung : ALFABETA.

Sujiono, Yuliani Nurani. (2009). Konsep Dasar Pendidikan Anak Usia Dini. Jakarta: PT Indeks. 